\title{
HAPPINESS AS A VALUE FOR A PRESCHOOL CHILD
}

In Happiness And Contemporary Society : Conference Proceedings Volume (Lviv, March, 20-21, 2021). Lviv: SPOLOM, 2021. P. 258-260. https://doi.org/10.31108/7.2021.57

ISBN 978-966-919-697-2

\section{ЩАСТЯ ЯК ЦІННСТЬ ДЛЯ ДИТИНИ-ДОШКІЛЬНИКА}

// Щастя та сучасне суспільство : збірник матеріалів міжнародної наукової конференції (Львів, 20-21 березня 2021 р.). - Львів : СПОЛОМ, 2021. С. 258-260. https://doi.org/10.31108/7.2021.57

ISBN 978-966-919-697-2 
SOLOVIOVA Liudmyla

Ph.D. in Psychology, Senior Researcher, G.S.Kostiuk Institute of Psychology of NAES of Ukraine (Kyiv, Ukraine)

\section{HAPPINESS AS A VALUE FOR A PRESCHOOL CHILD}

The article is devoted to the explaining of the features of the terminal value of "happiness" at the stage of its appropriation by a child of senior preschool age. The applied diagnostic methods are presented: "Express diagnostics of the sphere of value orientations of a preschooler" and observation "Diagnostics of the levels of manifestation of the activity structural component of the value orientations of senior preschoolers". The structure of values of preschoolers in the unity of their cognitive, emotional and activity components is outlined. The state of formation of the structure value-goal "happiness" of the studied children is characterized. Senior preschoolers' ideas about "happiness" is presented. The level of significance of "happiness" for children in comparison with other important values is determined: "family", "health", "creativity", "friendship", "money", "beauty of nature", "beauty of technology". It is established that "happiness" ranks first among effective values. It is concluded that senior preschoolers feel happy when they are involved in meaningful, independent, creative activities.

KEY WORDS: happiness, preschool child, structure of values, terminal values, value regulation.

\section{СОЛОВЙОВА Людмила}

Кандидат психологічних наук, старший науковий співробітник, Інститут психології імені Г.С.Костюка НАПН Украӥни (Київ, Україна)

\section{ЩАСТЯ ЯК ЦІННІСТЬ ДЛЯ ДИТИНИ-ДОШКІЛЬНИКА}

У новій редакції Базового компонента дошкільної освіти (Державного стандарту дошкільної освіти України), який затверджено наприкінці 2020 року, однією 3 цінностей дошкільної освіти визнане "щасливе проживання дитиною дошкільного дитинства як передумова ії повноцінного розвитку та подальшої самореалізації у житті" [1, с. 3]. Усвідомлення самоцінності дошкільного періоду життя дитини, його значущості для формування основ особистості вимагає від дорослих критичного перегляду усталених засобів педагогічного впливу на дитину-дошкільника. Прийдешні зміни потребують щонайменше врахування відповіді на питання: "Що робить дитину щасливою і як забезпечити її повноцінне та щасливе життя до школи?".

Наблизитися до відповіді на поставлені питання дозволили нам результати, одержані в ході виконання наукових досліджень 3 проблеми становлення ціннісних орієнтацій дітей дошкільного віку лабораторії психології дошкільника Інституту психології імені Г.С. Костюка НАПН України (2010-2020рр.).

Вивчення особливостей привласнення дитиною-дошкільником соціально значущих цінностей відбувалося 3 погляду розуміння цінностей як орієнтирів та регуляторів прояву особистісної активності. Для наукового аналізу було обрано термінальну та інструментальну модель цінностей M. Rokeach [4]. "Щастя" у цій 
моделі визначається в якості термінальної цінності - однієї з життєво важливих цілей (благ, мети існування), сфокусованих на особі.

Відомо, що маючи складну структуру цінності, окрім суттєвого емоційного компонента включають значущі когнітивний та діяльнісний, збалансованість розвитку яких визначатиме стійкість та дієвість цінностей як регуляторів дитячої поведінки. Важливо для створення повної картини власних цінностей дитинидошкільника мати можливість за допомогою адекватних дослідницьких інструментів визначити не лише рівень значимості цінностей для малюка, а й повноту уявлень про них, здатність управляти діями дитини під час діяльності. Для визначення структурної характеристики цінностей дитини-дошкільника та збалансованості їх емоційного, когнітивного та діяльнісного компонентів ми застосовували "Експрес-діагностику сфери ціннісних орієнтацій дошкільника" та спостереження "Діагностика рівнів прояву діяльнісного структурного компонента ціннісних орієнтацій старших дошкільників" [2; 3].

Діагностичним матеріалом першої методики слугувало 17 чорно-білих сюжетних картинок $(10 \times 10 \mathrm{~cm})$ із зображенням ситуацій взаємодії дитини 3 людьми, природою, технікою, мистецтвом, тотожних проявам 17 термінальних та інструментальних цінностей. У першій серії експерименту в процесі бесіди 3 дитиною за картинками "про важливе у житті" 3'ясовували іiі уявлення про усі означені поняття. Дитину просили вибрати певну картинку, наприклад, про щастя, та пояснити, що означає це слово. В результаті бесіди визначався рівень обізнаності дитини у змісті кожної цінності. У другій серії експерименту дитині пропонували відібрати вісім самих головних для неї картинок і послідовно їх викласти. В результаті оцінювання малюком важливості ціннісних характеристик i побудови їх ієрархії отримували рейтинг значущих для нього на той час цінностей.

Шляхом спостереження у закладах дошкільної освіти самостійної творчої діяльності дітей (сюжетно-рольової гри, малювання, конструювання, ліплення тощо) відзначалися факти дієвості привласнених дітьми термінальних та інструментальних цінностей, коли останні виявлялися, орієнтували та скеровували дії дитини протягом діяльності. Поведінка дитини аналізувалася за показниками, що свідчили про здатність старшого дошкільника ініціювати дії, умотивовані цінністю; послідовно їх реалізувати та долати труднощі на шляху здійснення цих дій. Визначалося три ступеня прояву кожного показника 3 відповідним оцінюванням у балах від 1 до 3.

Після обробки отриманих даних дослідження було визначено рейтинг кожної 3 цінностей 200 дітей старшого дошкільного віку за трьома категоріями: 1) обізнаність дитини у змісті цінності (когнітивний компонент /знана цінність); 2) важливість цінності для дитини (емоційний компонент/значима цінність; 3) здатність дитини керуватися цінністю у діях (діяльнісний компонент / дієва цінність.

У структурі цінностей старших дошкільників когнітивний компонент відображає дитячі уявлення про себе, предмети, об’єкти, явища оточуючої дійсності, які $є$ цінними для них. В рейтингу знаних цінностей досліджуваних дошкільнят "щастя" посіло 5 місце. Уявлення дітей старшого дошкільного віку про "щастя", яке уважалося доволі складним для інтерпретації маленькою дитиною поняттям, відрізнялися глибиною його змістового наповнення. Спостерігався суттєвий вплив на його тлумачення досвіду власних переживань дитини, іiі актуальних потреб і бажань, активності суб'єкта. Діти пов'язували "щастя" із можливістю займатися улюбленою справою ("гратися, малювати, будувати, подорожувати, спостерігати за природою та милуватися нею"), із гарним 
самопочуттям та задоволенням життям ("бути веселим; коли є радість; сталося щось хороше; коли я дарую щось мамі; коли все добре і збуваються мрії"), із благополуччям у сім’ї ("щаслива сім'я, у якій люблять і піклуються один про одного"), із прихильністю і взаєморозумінням між людьми ("дуже любити когось; коли люди ніколи не сваряться, не ображають один одного, роблять подарунки, радіють, веселяться") та 3 володінням матеріальними цінностями ("як ти багатий, то в тебе буде щастя, бо щось можна купити").

У списку цінностей за ознакою значущості, емоційної наповненості для старших дошкільників об'єктів, явищ чи якостей, що утворився в результаті дитячих виборів, "щастя" посіло 8 місце, поступаючись таким важливим для дітей цінностям як "сім’я", "здоров’я", "творчість", "дружба", "гроші", "краса природи", "краса техніки". Можливо, такий розподіл обумовлюється тим, що "щастя" є інтегрованим поняттям, яке у розумінні дітей об'єднує у собі усі попередньо обрані цінності, як джерела його забезпечення.

Натомість серед дієвих цінностей старших дошкільників "щастя" знаходиться на першому місці. Така позиція, на нашу думку, є закономірною, оскільки регулятивна дія цінності виявлялася в діяльності, найбільш бажаній для дітей, самостійно організованій та керованій ними. У процесі розгортання творчої сюжетно-рольової гри рольова активність дітей мала позитивний характер, приносила їм задоволення, спрямовувалася на партнерів по грі та досягнення спільного результату. Оскільки уявлення про "щастя" для багатьох дітей пов'язувалися 3 можливістю гратися 3 друзями, малювати, будувати тощо, то прагнення займатися улюбленою справою, бути учасником колективної гри, певним чином, організовувало дії дитини, підпорядковувало їх правилам, окресленими прийнятими ролями.

Отже, матеріали дослідження доводять, що старші дошкільники почуваються щасливими за умов залучення їх до значущої, самостійної, творчої діяльності. Це в свою чергу вимагає внесення певних змін в організацію життєдіяльності дітей в закладах дошкільної освіти: надання переваг провідній діяльності віку - самодіяльній творчій сюжетно-рольовій грі та іншим специфічно дитячим видам діяльності, ініційованим та вмотивованим самими дітьми, а не нав'язаним ззовні дорослими.

\section{ЛІТЕРАТУРА}

Про нову редакцію Базового компонента дошкільної освіти. URL: https://mon.gov.ua/storage/app/media/rizne/2021/12.01/Pro_novu_redaktsiyu\%20Ba zovoho\%20komponenta\%20doshkilnoyi\%20osvity.pdf. (дата звернення 14.02.2021).

Регулююча дія ціннісних орієнтацій у житті дитини: монографія / [Т.О. Піроженко, I.I. Карабаєва, О.Ю. Хартман, Л.І. Соловйова, О.І. Федорчук, Л.Д. Токарєва]; за ред. Т.О. Піроженко. Київ : Видавничий Дім "Слово", 2020. 222 с. URL: https://lib.iitta.gov.ua/722164/. (дата звернення 14.02.2021).

Соловйова Л.І. Термінальні та інструментальні цінності дітей старшого дошкільного віку. Актуальні проблеми психологї̈ : зб. наук. пр. Інституту психології імені Г.С. Костюка НАПН України. Харків, 2020. T. IV. Психологія розвитку дошкільника. Вип. 16. С. 162-178.

Rokeach, M. (1973). The nature of human values. New York, NY: Free Press. 438 p. 